\title{
Factors that Influence the Implementation of Early Initiation of Breastfeeding in RSUP Haji Adam Malik Medan
}

\author{
Ali Imron ${ }^{1}$, Ida Yustina ${ }^{2}$, Etti Sudaryati ${ }^{2}$ \\ ${ }^{1}$ Master Student in Faculty of Public Health, Universitas Sumatera Utara, Medan, Indonesia \\ 2Lecturer in Faculty of Public Health, Universitas Sumatera Utara, Medan, Indonesia \\ Email: aliimron.skm@gmail.com
}

\begin{abstract}
:
Early Initiation of Breastfeeding (EIB) is placing the baby in the mother's stomach immediately after birth in a position of skin contact with the mother in an hour after birth, if there is no medical indication. RSUP Haji Adam Malik Medan was one of the government hospitals, education, national referrals, and plenary status had implementing EIB. Achievement of EIB in this hospital decreased from (27.71\%) in 2016 to (23.08\%) in 2017. The purpose of this study was to explore the implementation of EIB in RSUP Haji Adam Malik Medan. This was a qualitative research with a phenomenological approach through in-depth interviews. The informants were 6 people, consisting of 2 midwives and 1 structural official in medical services, 2 patients and 1 gynecologist. Implementation of EIB in the hospital wasn't going well, the factors that influence EIB were communication, disposition and management's function. The successful implementation of EIB can reduce maternal and infant mortality rates, suggested to RSUP Haji Adam Malik Medan forms a special team to monitoring and evaluates the implementation of EIB, set and carry out sanctions for implementation of EIB, and increases the competence and motivation of health workers.
\end{abstract}

Keywords:

early initiation of breastfeeding; hospital; communication; disposition and management's functions

\section{Introduction}

Optimal breast milk during infancy is very important, especially during the first hour. The baby was given the opportunity to be able to suckle themselves directly since the birth of the baby with the criteria between mother and baby skin contact occurs at least one hour after birth, if there are no cons medical indications (healthy) commonly called Early Initiation of Breastfeeding. Early Initiation of Breastfeeding was very important to stimulate the release of Mother's Milk and an initial guarantee of breastfeeding until the baby gets Exclusive Breast Milk for the next six months.

Breastfeeding was very beneficial for babies and their mothers. Increasing the achievement of babies who had EIB at birth and continued with exclusive breastfeeding will have the impact that many children under five years old can be saved each year, the majority of which were 87 percent of babies under the age of six months; and can protect new mothers from illness and death after childbirth.

The achievement of the implementation of EIB and Exclusive Breastfeeding in the World was still far from the target. The latest data in 2017 shows that EIB achievement was still 44 percent of the 70 percent target set, and Exclusive Breastfeeding 40 percent from the 60 percent target set. 
The trend of Exclusive Breastfeeding achievements in Sumatra Utara from 2015-2017 continues to decline, starting from 33 percent, 12.4 percent and 10.73 percent.4, 5, 6 This downward trend wasn't in line with the number of national targets that must be achieved and had an upward trend, namely: 39 percent, 42 percent and 44 percent. Meanwhile, the achievements of the implementation of Early Inititaion of Breastfeeding from 2016 to 2017 tended to increase from 36.4 percent to 42.2 percent. However this achievement had not reached the national target of 41 percent in 2016 and 44 percent in 2017.

In order to guarantee the right of a baby in getting Early Initiation of Breastfeeding, Article 128, paragraph (1) of Indonesia Law No. 36/2009 on Health states that every baby has the right to get exclusive breastfeeding from its mother since it is born until it is 6 (six) months old, unless there is medical indication; paragraph (2) of the same Law states that during the exclusive breastfeeding, family members, central government, local government, and community should completely support the mother by providing specific time and facility, and paragraph (3) states that specific facility should be provided at work places and at public places.7 In order to Realize Article 128, the government issued Government Regulation No. 33/2012 about Exclusive Breastfeeding. In Article 9 of this Government Regulation, paragraph (1) states that Health workers and Health Service Facility providers must start breastfeeding newborns early to their mothers for at least 1 (one) hour, and paragraph (2) Early Initiation of Breastfeeding was done by placing the baby on the mother's chest or abdomen so that the baby's skin sticks to the mother's skin.

However, the percentage of babies who received exclusive breastfeeding in Medan, still showed a decrease from 2015 to 2016, in 2015 the percentage of exclusive breastfeeding reached 40.1 percent and decreased in 2016 to 30.9 percent.

RSUP Haji Adam Malik Medan was one of three government hospitals located in Medan. This hospital in its development, by the Ministry of Health has been used as an Educational Hospital and Center for Referrals covering the Provinces of Aceh, Riau, West Sumatra and North Sumatra, and has been accredited with Plenary Level status.

This hospital had Standard Operating Procedures (SOP) to support health workers in the implementation of Early Initiation of Breastfeeding, but the results had decreased from 2016 to 2017, which amounted to 27.71 percent in 2016 and to 23.08 percent in 2017 (Medical Records Section-RSUP Haji Adam Malik Medan, 2018) and This showed that the Standard Operating Procedure for Early Initiation of Breastfeeding had not gone well in the Hospital.

Similar research on the implementation of EIB in hospitals had been carried out, where the dominant factor affecting IMD wasn't yet due to the lack of standard operating procedures in hospitals. The hospital already had a standard operational procedure, but it has not yet run well, based on the description above, research was conducted with the aim to explore the factors that influence the implementation of Early Initiation of Breastfeeding at RSUP Haji Adam Malik Medan.

\section{Research Method}

This research was a qualitative with a phenomenological design through in-depth interviews conducted from July to November 2018. The determination of informants in this study was by purposive sampling, taking data sources with certain considerations. There were 6 informants in this study, consisting of 2 main informants, 1 key informant, and 3 supporting 
informants as well as triangulation informants. The main informant in this study was the implementing midwife, with the key informant being a structural official in medical services and supporting informants was patients and gynecologist. The results of in-depth interviews were analyzed using the method of Moustakas, C. (1994); the results of the interview were transcribed into written language (verbatim), then inventoryed with important statements relevant to the topic, classifying statements for coding, and presenting the results of research to the reader about how someone experiences the phenomenon.

\section{Discussion}

RSUP Haji Adam Malik was located at seventeen Bunga Lau Street, Kemenangan, Medan Tuntung Sub-district, Medan, Sumatera Utara, with a distance of approximately 14 kilometers from the center of Medan and approximately one kilometer from Jamin Ginting street.

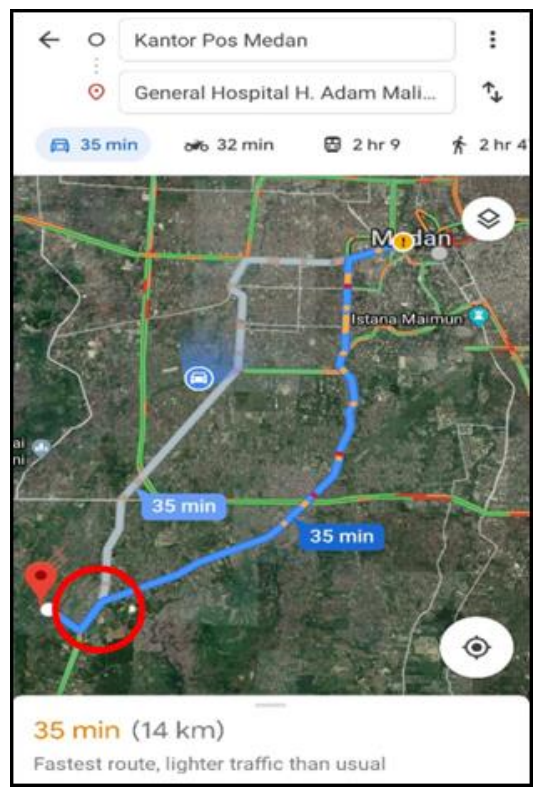

Figure 1. The location of RSUP Haji Adam Malik Medan

\subsection{Details of Informant}

The informants in this study were all females. For key informants, there are 2 midwives, on average, who had worked for up to 20 years and were currently in their 50s. Midwives who work in hospitals are required to be had at least a Diploma III level in midwifery and a certificate of expertise such as comprehensive emergency neonatal obstetric care training, delivery care and Midwifery Update.

The key informant of this study was a structural official who served in the hospital's medical services. Supporting informants, amounting to 3 people consisted of 1 patient with vaginal delivery, 1 patient with sectio caesarean delivery, and 1 gynecologist.

\subsection{Implementation of EIB}

In a similar study conducted by Siregar, it showed that the unavailability of Standard Operating Procedures caused the implementation of Early Initiation of Breastfeeding in Rumah Sakit Umum Daerah (RSUD) Padangsidimpuan not going well.

Research conducted by Yustina and Aini on the rights of infants in obtaining exclusive breastfeeding by families in rural areas, show that one obstacle to the implementation of the 
exclusive breastfeeding policy was the absence of supporting regulations that regulate the prohibition of formula milk feeding for aged infants under six months, despite regulations that require babies to be entitled to exclusive breastfeeding.

Likewise, research conducted by Wahyuningsih on the analysis of the implementation of Early Initiation of Breastfeeding (EIB) by midwives of the inpatient health center in Sukoharjo District, shows that one of the reasons for not yet initiating maximum early breastfeeding was due to the absence of written rules regarding EIB in the inpatient health center located in Sukoharjo District.

Based on the description above, information was obtained that one of the factors that can influence the success of the implementation of a policy, such as Early Initiation of Breastfeeding or Exclusive Breastfeeding was the availability of regulations or policies.

Through interviews conducted with first informant (a structural official who served in the hospital's medical services) as a key informant, information was obtained if RSUP Haji Adam Malik Medan already had a standard operational procedure regarding early initiation of breastfeeding. Standard operating procedures are based on:

1. Law No. 36 of 2009 concerning health guaranteed the right of every baby to get exclusive breastfeeding (ASI) for the first 6 (six) months since birth except on medical indications, and requires the family, government, local government, and the community to support the baby's mother providing full-time and special facilities;

2. Government Regulation No. 33 of 2012 concerning the Provision of Exclusive Breastfeeding that requires health workers and providers of health care facilities must initiate early breastfeeding of newborns to their mothers for at least 1 (one) hour by placing the baby on his stomach on the mother's chest or abdomen so that baby's skin was attached to the mother's skin; and

3. Needs in preparation for evaluating hospital accreditation on a national and international scale.

Implementation of Early Initiation of Breastfeeding at Haji Adam Malik Medan was still not going well, even though it already had standard operational procedures for Early Initiation. Some of the factors that influence it were as follows:

\section{a. Communication}

According to First Informant, Information about Standard Operating Procedures for early initiation of breastfeeding was disseminated to all implementing midwives in the Obstetrics Section of Emergency Department. Based on interviews conducted with midwives (second and third informants) who were implementing midwives services, they stated that the standard operational procedures had been transmitted to them, but the socialization activities were only carried out once.

Submission of information that was only done once by the education and training department was still seemed to be less than optimal. These activities should be carried out continuously without changing the context of the standard operating procedures in accordance with what was intended by policy makers. The socialization that was only delivered once to implementing midwife had an impact on the incompatibility of the understanding that the implementing midwife had with what was meant by the policy makers. When conducting interviews with implementing midwives related to the content contained in standard operational procedures, second and third informants provided answers that did not match 
those listed.

Some of the things that the informant answers were mismatched, such as when asked the purpose of the standard operating procedures, the answer was to provide protection to the implementing midwife and support government activities, and to make the baby healthier. The objectives of the standard operating procedures were to: 1) reduce infant mortality; 2) Keep the baby's temperature warm; 3) Calms the mother and baby and regulates baby's breathing and heartbeat; 4) Colonization of "good" bacteria in the skin and intestines of infants with normal maternal body bacteria to care for the baby; 5) Reducing the crying baby to reduce stress and energy used by the baby; 6) Allows the baby to find her own breasts and attach themselves so rarely find difficulty breastfeeding; and 7) Increasing the love relationships of the mother, father and baby.

Midwives also do not have a good understanding of the stages of the implementation of Early Initiation of Breastfeeding listed in the Standard Operating Procedures that have an impact on errors during implementation. First, mothers and husbands should be sure to agree on the EIB plan after getting an explanation before the delivery in the education room, but from observation, it was found that education carried out by the implementing midwife while the delivery will take place in the delivery room, moreover, information obtained from fourth informant (24 years) with vaginal delivery, he said there was no education about the initiation of early breastfeeding before delivery.

Second, the midwife was required to support and help the mother to understand the baby's behavior before breastfeeding, but still touch the mother for at least one hour. Based on interviews with second and third informants, information was obtained that after giving birth the baby was allowed to touch and suckle the mother, but with an average duration of only up to 30 minutes. Whereas information obtained from the fourth informant stated that the baby was placed on the mother's body in less than 5 minutes because the baby had received her breast milk, and this information was continued by fifth Informant ( 25 years) by caesarean delivery, that the baby was immediately taken to the incubator to be warmed and there was not an opportunity for early breastfeeding. This kind of incident was also justified by the sixth informant ( 60 years) gynecologist who stated that the initiation of early initiation of breastfeeding only lasted up to 15 minutes, because the midwife had to care for the baby.

Third, babies who were allowed not to get the chance to early breastfeeding when newborns are babies with medical indications, no mothers and mothers who must be separated from babies due to unhealthy maternal conditions. Based on the results of interviews with first, second and third informants, obtained information that all babies and mothers who were healthy after giving birth, certain to initiate early breastfeeding, except for referral patients whose conditions were emergency with accompanying diseases such as bleeding, eclampsia, hepatitis, and human immunodeficiency virus/ HIV. This statement was not yet fully implemented; it can be seen from the statement of fifth informant, where the baby was immediately taken to the incubator after birth to be warmed up and there was no chance to early breastfeeding, while the condition of the baby and mother was healthy and there was no medical indication as mentioned above.

Some experts said that if there was a possibility of transmission or transfer of the disease to the baby, it was permissible for the baby not to receive milk from his mother. However, not all diseases were transmitted directly from mother's milk, but transmitted through physical contact, respiratory tract and poor sanitary hygiene, which can be prevented 
from transmission such as typhoid fever, tuberculosis and chickenpox. Only HIV can be transmitted directly through mother's milk.

Hogwood and Gunn in Wahab, said to be able to implement public policies perfectly, it was necessary to have a good understanding of the implementers of policies and an agreement on the same goals between policy makers and implementers.

According to Edward in Winarno, in order for policies to be implemented to run or the implementer works as expected by the maker, the implementation instructions must not only be accepted by the implementer, but have to delivered understood clearly and easily as well as the consistency and information repeatedly.

\section{b. Disposition}

Interviews conducted by researchers with second and third informants found that all parties involved support the implementation of Early Initiation of Breastfeeding, starting from the availability of standard operational procedures, appointment of officers according to needs, because the fulfillment process has been through workload analysis, to the provision of facilities for development careers in the form of midwife training. However, this support was not able to improve the achievement of early initiation of breastfeeding in the hospital.

The assignment of the implementing midwife who works in the midwifery room was adjusted to the calculation of the workload, competencies and qualifications set by the hospital. In providing training opportunities in the context of career development, all health workers on duty such as implementing midwives cannot be felt. The midwife profession demands to participate in activities in order to add insight into the latest midwifery with additional benefits obtained in the form of credit unit numbers that can be used to extend the registration certificate of health workers. This registration certificate is very necessary for health workers in order to carry out their profession both for independent practice or serving in hospitals. This limitation had an impact on midwives who eventually collaborate with sponsors from formula milk producers. Although it does not directly affect the optimal implementation of early initiation of breastfeeding and exclusive breastfeeding in hospitals, it had an impact on the implementation of early initiation of breastfeeding at the place where midwives carry out their practice. This collaboration carried out in order to facilitate the midwife to attend seminars and trainings that cannot be accommodated by hospitals, and through this activity, finally the midwife gotten credit points to extend her practice license and facilitate her career development.

According to Edwards in Winarno, the disposition of policy makers and implementers had many important consequences for implementing policies effectively. If the attitude of the policy implementer was good or supportive towards the existence of the policy, appointing bureaucrats appropriately, and manipulation of good incentives can be carried out, it is likely that the policy implementer will implement the policy according to what was desired from the policy maker, and vice versa, the actions or perspectives of the implementer policies are different from policy makers, so the implementation of policies will become increasingly difficult.

A similar study was conducted by Stevani, which was about the Process of Accreditation Preparation for Kertek II Health Center; the results showed that the disposition characteristics of the implementers which did not fully support the implementation of the accreditation preparation of the Kertek II Health Center became one of the obstacles to the 
smooth running of activities.

The results of Subekti et al. show that disposition in the form of support from school principals, teachers and committees, as well as support from parents of students can influence the effectiveness of the implementation of the School Operational Assistance policy at Public Elementary Schools in Tambak District.

\section{c. Management's functions}

Planning and budgeting activities according to first informant are carried out annually, which were compiled into a single hospital's Basic Budget Plan document. Details were compiled based on the needs of each unit, then proposed to the installation for further discussion with management and education and training, and submitted to the director for approval. The contents of the Budget Basis Plan document do not only contain budget requirements, but also include facilities, health workers and training needs.

Second Informant said that the midwifery section at the Emergency Room also annually proposes the need to support the implementation of midwifery service activities, one of which was the proposal for seminars and training activities. This statement was justified by first informant, only when it was ratified that only around 1-2 people/activities each year, with consideration, the number of human resources in the hospital and need to be accommodated, so the education and training section needs to set priorities, and limitations this impacts midwives who collaborate with formula milk producers.

The implementation of the early initiation of breastfeeding policy has not gone well, one of which was due to the lack of supervision. Even though the activity plan was prepared well, the placement of health workers in accordance with competence, but without supervision can have an impact on the implementation of activities that were not in accordance with the standards, including early initiation of breastfeeding activities.

Third Informant said that at the time of delivery, the one responsible for getting the newborn to have the opportunity to breastfeed early was the implementing midwife, and the duty to supervise was the midwife who was the leader during the delivery process. Additional information involved in childbirth is usually the obstetrician, pediatrician, PPDS doctor (Participant in the Specialist Education Program), and midwife. According to second informant, so far the midwife carries out the task only in reference to her profession and experience as a midwife, and feels that the standard operating procedures were not much different from her professional duties, so it was not a problem, even if she works without supervision. Based on information submitted by sixth informant, to date there were no supervision and evaluations of early initiation of breastfeeding activities in hospitals.

In order for a program or policy to work well, supervisors who were given responsibility should not only come from the internal team, but also need supervision from outside or the external team who had a special task and independent, in addition has no connection with the team.

Kotter's article, titled "What Leaders Really Do" in the Harvard Business Review in December 2001, there were 3 basic things about management, first related to planning activities and budgets. Second was related to the organization and staffing or appointment of staff, and third was related to controlling, namely supervision and problem solving obtained after evaluating activities. 
Based on research conducted by Anwar, the management function of the leader or head of the room in planning, organizing, staffing, and controlling had a relationship with the application of patient safety culture.

\section{Conclusion}

Based on the results and discussion above, it can be concluded that the implementation of early initiation of breastfeeding in hospitals did not go well. The factors that influence it were communication (transmission, consistency, and understanding); disposition (commitment, support, appointment of bureaucracy); management's functions (planning and supervision).

Suggestions that the implementation of early initiation of breastfeeding can run well was with: Forms a special team to monitoring and evaluates the implementation of early initiation of breastfeeding; Set and carry out sanctions for implementation of early initiation of breastfeeding; and Increases the competence and motivation of health workers providing training and rewards.

\section{Acknowledgements}

I am especially thankful to all the informant who answered the questions. I would like to extend my thanks to the health ministry for their assistance and cooperation in research funding. I am grateful to my colleagues for their advice and support throughout the study.

\section{References}

Maryunani, A. (2015). Inisiasi menyusu dini, ASI Eksklusif dan manajemen laktasi. Jakarta: CV. Trans Info Media.

UNICEF. (2018). Breastfeeding: a mother's gift, for every child, New York: UNICEF.

UNICEF. (2017). Global breasfeeding scorecard: tracking progress for breastfeeding policies and programmes, New York: UNICEF.

Kementerian Kesehatan Republik Indonesia, (2015). Profil kesehatan Indonesia Tahun 2015, Jakarta: Kementerian Kesehatan Republik Indonesia.

Kementerian Kesehatan Republik Indonesia, (2016). Profil kesehatan Indonesia Tahun 2016, Jakarta: Kementerian Kesehatan Republik Indonesia.

Kementerian Kesehatan Republik Indonesia, (2017). Profil kesehatan Indonesia Tahun 2017, Jakarta: Kementerian Kesehatan Republik Indonesia.

Undang-Undang Kesehatan RI No. 36 Tahun 2009.

Peraturan Pemerintah No. 33 Tahun 2012 Tentang pemberian air susu ibu eksklusif.

Dinas Kesehatan Kota Medan, (2015). Profil kesehatan Kota Medan Tahun 2015, Medan: Dinas Kesehatan Kota Medan.

Dinas Kesehatan Kota Medan, (2016). Profil kesehatan Kota Medan Tahun 2016, Medan: Dinas Kesehatan Kota Medan.

Dinas Kesehatan Provinsi Sumatera Utara, (2016). Profil kesehatan Provinsi Sumatera Utara Tahun 2016, Medan: Dinas Kesehatan Provinsi Sumatera Utara.

Moustakas, C. (1994). Phenomenological research methods. Sage.

Siregar, H.H. (2018). Implementasi program inisiasi menyusu dini di RSUD Kota Padangsidimpuan. (Tesis, Universitas Sumatera Utara). Diakses dari http://repositori.usu.ac.id/bitstream/handle/123456789/6522/157032084.pdf?seque nce $=1$ \&isAllowed $=y$. 
Yustina, I., \& Aini, F. (2017). The baby's rights in Exclusive Breastfeeding by family in Suburban Areas. Atlantis Press, 1(1), 174-177. doi: 10.2991/phico-16.2017.46.

Wahyuningsih, E. (2015). Analysis of Implementation of Early Initiation of Breastfeeding (IMD) by the Midwife Public Health Center In Sukoharjo District. Prosiding University Research Colloquium, 1(100), 659-672.

Getahun, H., Sculier, D., Sismanidis, C., Grzemska, M., \& Raviglione, M. (2012). Prevention, diagnosis, and treatment of tuberculosis in children and mothers: evidence for action maternal, neonatal and child health services. The Journal of Infectious Diseases, 205(suppl_2), S216-S227. doi:10.1093/infdis/jis009.

Nduati, R., John, G., Ngacha, D.M., Richardson, B., Overbaugh, J., Mwatha, A., ... \& Kreiss, J. (2000). Effect of breastfeeding and formula feeding on transimission of HIV-1. Journal American Medical Association, 283(9), 1167-1174. doi: 10.1001/jama.283.9.1167.

Rhandhawa, V.S., Kumar, A., Saili, A., Datta, V., Agrawal, C., \& Mehta, G. (2007). Paratyphoid sepsis, India: Indian J Pediatr.

Shrim, A., Koren, G., Yudin, M.H., Farine, D., \& Maternal Fetal Medicine Committee. (2012). Management of varicella infection (chickenpox) in pregnancy. Journal of Obstetrics and Gynaecology Canada, 34(3), 287-292. doi: 10.1016/s1701-2163(16)35190-8.

Wahab, S.A. (2016). Analisis Kebijakan: dari Formulasi ke Penyusunan Model-Model Implementasi Kebijakan Publik, Jakarta: PT. Bumi Aksara.

Winarno, B. (2016). Kebijakan publik era globalisasi: teori, proses dan studi kasus komparatif. Jakarta: Center of Academic Publishing Service.

Stevani, Y. (2019). Proses Persiapan Akreditasi Puskesmas Kertek II. HIGEIA Journal of Public Health Research and Development, 3(1), 12-23. doi: 10.15294/higeia/v3i1/24881.

Subekti, M., Faozanudin, M., \& Rokhman, A. (2017). Pengaruh komunikasi, sumber daya, disposisi dan struktur birokrasi terhadap efektifitas implementasi program bantuan operasional sekolah pada satuan pendidikan Sekolah Dasar Negeri di Kecamatan Tambak. IJPA-The Indonesian Journal of Public Administration, 3(2), 58-71.

Kotter, J.P., (2001). Harvard Business Review: What Leaders Really Do. Boston: Harvard Business Publishing, 79 (11).

Anwar., Rochadi, K.R., Daulay, W., \& Yuswardi. (2016). Hubungan fungsi manajemen kepala ruang dengan penerapan patient safety culture. Idea Nusring Journal, 7 (1), 26-34. 